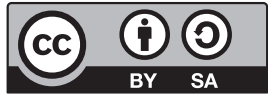

https://doi.org/10.31261/IJREL.2020.6.2.06

\author{
Olena Semenikhina \\ Makarenko Sumy State Pedagogical University, Ukraine \\ https://orcid.org/0000-0002-3896-8151
}

\title{
Volodymyr Proshkin
}

Borys Grinchenko Kyiv University, Ukraine

https://orcid.org/0000-0002-9785-0612

\section{Olha Naboka}

Donbas State Pedagogical University

https://orcid.org/0000-0003-4635-0009

\section{Application of Computer Mathematical Tools in University Training of Computer Science and Mathematics Pre-service Teachers}

\begin{abstract}
The requirements for the training of mathematics and computer science teachers to use specialized mathematical software in professional activities are substantiated in the article. Among them: the ability to creatively choose the forms and methods of teaching for the use of specialized software; ability to find non-standard or creative mathematical problems; ability to make an informed choice of specialized software; ability to see possible ways to check the result obtained by the pupil; the ability to eliminate common mistakes when pupils use computer tools, etc. The specialized mathematical software, which is used today in mathematical training of mathematics and computer science teachers in Ukraine, has been specified. The specialized mathematical software which is used today for teaching mathematics in schools of Ukraine is given. The analysis of computer tools used by the teacher in the most common mathematical software is carried out. The most urgent problems faced by mathematics teachers in their professional activities are
\end{abstract}


highlighted. The experiment with ninth-grade pupils proved the positive impact of using dynamic geometry software and appropriate mathematical tools on the level of pupils' mathematical training, which is reason to talk about the importance of computer science and mathematics pre-service teacher training to involve such tools in professional activities. Prospects for further research in the direction of developing methods for using computer mathematical tools in a research-based learning environment are presented.

K e y w or d s: computer mathematical tools; dynamic geometry software; computer algebra system; pre-service teacher of mathematics; pre-service teacher of computer science; university education

The professionalism of a modern teacher of computer science and mathematics is not only their competence in various fields of mathematical knowledge and computer science, their high qualifications, which are the key to successful work. Teachers of computer science and mathematics are required not only to use traditional forms and methods of education but also innovative ones, related in particular to digital technologies. Considering that a significant content of education at the University of computer science and mathematics teachers is occupied by mathematical disciplines, the problem of training teachers for the use of specialized software deserves attention. In our opinion, this problem can be considered along the following lines:

- clarification of specialized software for mathematics, which is now used in mathematical training of computer science and math teachers;

- finding out the problems faced by math teachers in their professional activities, even if they are familiar with specialized mathematical software;

- clarification of the list of knowledge and skills required by computer science and math teachers for use in professional activities of specialized mathematical orientation Program Soft.

\section{Literature Review}

Analysis of scientific publications in the field of mathematics gives grounds to talk about the use of certain types of specialized software: computer algebra systems (CAS) and dynamic geometry software (DGS). The former include such 
Application of Computer Mathematical Tools in University Training of Computer Science...

programs as Maple, Mathematica, Maxima, and others, the latter - GSP (The Geometer's Sketchpad), GeoGebra, GRAN, DG, and others. Among the first type of programs, there are none offered by Ukrainian developers, which is explained by objective circumstances of lack of sufficient funding for such projects. Among the second type of programs, we note the Ukrainian GRAN and DG, which were once recommended for use in Ukrainian schools, but also stopped improving due to lack of funds.

Analysis of scientific and methodological publications on the specialized software use in the field of mathematics gives grounds to talk about the active use of the second type programs (DGS). Thus, Semenikhina and Drushlyak described some aspects of such programs use in the schools of Ukraine (Semenikhina \& Drushlyak, 2015). Henseruk characterized the professional competence of a teacher, where the component is digital competence, which, among other things, involves the teacher's ability to use specialized software (Henseruk, 2019).

Stols and Kriek examine the influence of mathematics teachers' beliefs on their intended and actual usage of dynamic mathematics software in their classrooms. The theory of planned behavior, the technology acceptance model, and the innovation diffusion theory was used to examine the influence of teachers' attitudes, subjective norms, and perceived behavioral control on their intention to use dynamic mathematics software in their classrooms (Stols \& Kriek, 2011). Hohenwarter and Preiner describe a study aimed to identify the most common impediments related to the introduction of an open-source mathematical software package GeoGebra. The study identified the challenges participants face during workshops and evaluated the difficulty levels of GeoGebra tools (Hohenwarter \& Preiner, 2007). Saha, Ayub, Tarmizi investigated the peculiarities of using GeoGebra in the learning of coordinate geometry among students classified as high visual-spatial ability students and low visual-spatial ability students. The results of the study show that the use of GeoGebra enhanced the students' performance in learning coordinate geometry (Saha, Ayub \& Tarmizi, 2010). Similar positive results were obtained in the study of Zengin, Furkan, Kutluca, which determined the effects of dynamic mathematics software GeoGebra on student achievement in the teaching of trigonometry (Zengin, Furkan \& Kutluca, 2012).

Botana, Hohenwarter, Yanichich and others identified a number of GeoGebra features (integration of computer algebra, dynamic geometry, spreadsheet, etc.), that allow student experiments, in particular, in the context of proving theorems (Botana, Hohenwarter, Yanichich, et al. 2015). Dubrovskyi substantiated the basic principles of using the program Mathematical Constructor (Dubrovskyi, 2016). Morozova and Myroshkina presented methodological principles of work with the program Living Mathematics, which is a Russian equivalent of GSP (Morozova \& Myroshkina, 2013).

IJREL.2020.6.2.06 p. 3/23 
Also noteworthy are studies on innovative teaching methods, in particular mathematics and computer science. Let us turn to the work "Innovative Pedagogical Methods in the Digital Era," which presents the following methods: Blended Learning, Flipped Learning, Problem Based Learning, Inquiry Based Learning (Dziabenko, 2020).

At the same time, our analysis of the scientific literature allowed us to establish that the issue of training pre-service teachers of mathematics and computer science to use specialized mathematical software in professional activities remains insufficiently researched. The development of software and its constant updating determine the new requirements for mathematics and computer science teachers' knowledge and skills in the field of using specialized Program Soft, the development of mathematical competence through e-learning, which is emphasized in the study of Heba, Kapounova, Smyrnova-Trybulska (Heba, Kapounová \& SmyrnovaTrybulska, 2014).

\section{The Aim of the Article}

The aim of the article is to determine the requirements for the training of math and computer science teachers to use specialized mathematical software in professional activities.

The goal led to the solution of several tasks:

1) clarification of specialized mathematical software, which is currently used in mathematical training of math and computer science teachers in Ukraine;

2) clarification of specialized mathematics software, which is currently used for teaching mathematics in schools of Ukraine;

3) analysis of computer tools used by teachers in the most common mathematical software;

4) clarification of the problems faced by mathematics teachers in their professional activities;

5) clarification of the list of knowledge and skills required for mathematics and computer science teachers to use specialized mathematical software in professional activities. 
Application of Computer Mathematical Tools in University Training of Computer Science...

\section{Methodology of Research}

To solve the first and second tasks, a survey was used, which consisted in the study of answers to the questions: "What mathematical software is used in teaching the following disciplines: mathematical analysis, linear algebra, analytical geometry, projective geometry, differential equations, differential geometry and topology, mathematical modeling, linear programming, group theory, probability theory and mathematical statistics, complex analysis, teaching methods"; "What mathematical software is used in teaching algebra and the beginnings of analysis, plane geometry, stereometry."

The sample for the first task consisted of 13 lecturers who had the experience of teaching a given discipline for at least five years, and numbered by discipline: mathematical analysis - 11, linear algebra - seven, analytical geometry - five, projective geometry - three, differential equations - 11, differential geometry and topology - three, mathematical modeling - four, linear programming - five, group theory - three, probability theory and mathematical statistics - three, complex analysis - five, teaching methods - three.

The sample for the second task was 73 teachers who had the experience of teaching senior classes for at least three years. Based on the results of first and second tasks, the most popular software type was selected. For this type, the analysis of available computer tools was carried out and the list of the most popular ones in the work of mathematics and computer science teachers was compiled.

To solve the fourth task, an expert survey was conducted: "Specify the problems faced by teachers of mathematics and computer science when using specialized mathematical software." The experts were teachers-methodologists and teachers of the highest category with a total number of five people.

The consistency of experts' opinions was assessed by the Kendall concordance coefficient. According to the results of the examination, the concordance coefficient $\mathrm{W}$ was determined by the formula:

$W=\frac{12 \sum_{j=1}^{n} d_{j}^{2}}{m^{2}\left(n^{3}-n\right)-m \sum_{i=1}^{m} T_{i}}, d_{j}=S_{j}-\frac{\sum_{j=1}^{n} s_{j}}{n}, S_{j}=\sum_{i=1}^{m} R_{i j}, T_{i}=\sum_{l=1}^{L}\left(t_{l}^{3}-t_{l}\right)$

$R_{i j}$ - rank, assisted by the $i$ expert to the $j$ problem;

$m$ - the number of experts, $n$ - the number of problems;

$l$ - the number of the same (related) ranks groups;

$T_{i}$ - the number of related ranks in each group.

If the value of the concordance coefficients is close to 1 , then obtained data indicate a high degree of experts' agreement.

IJREL.2020.6.2.06 p. 5/23 
The fifth task was solved by systematizing and summarizing the results of previous tasks.

The work was performed within the scope of scientific topics: "Theoretical and practical aspects of the use of mathematical methods and information technology in education and science" (registration number 0116U004625) Department of Computer Science and Mathematics, Borys Grinchenko Kyiv University and "Use of information technology in education" (registration number № 0111U005734) Department of Computer Science, Makarenko Sumy State Pedagogical University.

\section{Results of Research}

The results of task 1 are summarized in Table 1. It is worth noting that each respondent could indicate any number of the proposed software.

Table 1.

The results of the lecturers survey (\%)

\begin{tabular}{|c|c|c|c|c|c|c|c|c|c|c|c|c|}
\hline & 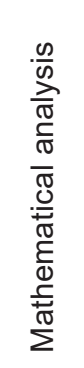 & 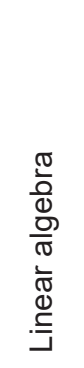 & 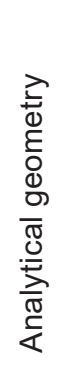 & 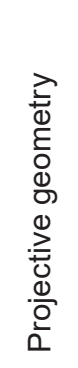 & 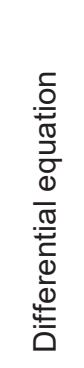 & 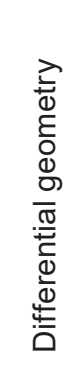 & 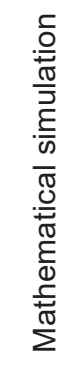 & 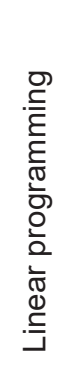 & 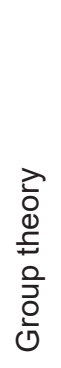 & 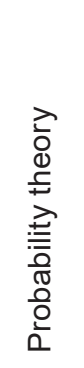 & 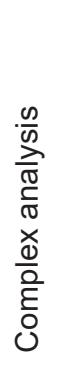 & 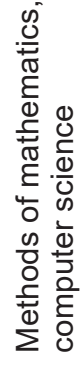 \\
\hline Maple & 0.18 & 0.14 & & & 0.18 & 0.33 & 0.25 & 0.2 & & & & \\
\hline \multicolumn{13}{|c|}{ Mathematica } \\
\hline Maxima & 0.27 & 0.29 & & & 0.27 & & & 0.2 & & & & \\
\hline $\mathrm{R}$ & 0.09 & 0.43 & & & 0.09 & & & & & & & \\
\hline Mathlab & 0.45 & 0.29 & 0.4 & & 0.45 & 0.33 & & & & & & \\
\hline Geogebra & & & 0.6 & 0.33 & & & 0.25 & & & 0.33 & & 0.66 \\
\hline Mathkit & & & & & & & & & & & & 0.66 \\
\hline GSP & & & & & & & & & & & & 0.33 \\
\hline other & & & & & & & & & & & & 0.33 \\
\hline
\end{tabular}

IJREL.2020.6.2.06 p. 6/23 
Application of Computer Mathematical Tools in University Training of Computer Science...

According to the results of the survey, there are specific reasons to talk about the popularity of the first type of specialized mathematical software: Maple, Maxima, Mathlab, as well as program of the second type. The reasons are, as follows: the choice of Maple powerful tools, a wide range of tasks that the program helps to solve; the choice of Maxima by free distribution and sufficiently powerful tools for solving mathematical problems of the university course of mathematics for teachers; Mathlab's choice of toolkit power and significant prevalence among universities; Geogebra's choice of free distribution, specificity and constant updating of tools, which allows expanding the range of mathematical problems.

It should be noted that as the result of the training, mathematics and computer science teachers will be familiar with the mentioned programs and will be able to solve a range of mathematical problems based on their tools. The results of task 2 are presented in Table 2.

Table 2.

The results of teachers survey (\%)

\begin{tabular}{lccc}
\hline & $\begin{array}{c}\text { Algebra and the beginnings } \\
\text { of analysis }\end{array}$ & Plane geometry & Stereometry \\
\hline Maple & 0.11 & & \\
Mathematica & 0.11 & & \\
Maxima & & & \\
R & & & 0.82 \\
Mathlab & 0.73 & 0.73 & \\
Geogebra & 0.62 & 0.62 & 0.55 \\
Mathkit & & 0.25 & 0.07 \\
GSP & & 0.07 & 0.44 \\
Cabri & 0.44 & 0.44 & \\
Gran & & 0.3 & \\
DG & & & \\
other & & & \\
\hline
\end{tabular}

According to the results of the survey, the second type of software is popular in teaching mathematics at school, with Geogebra and Mathkit being the most popular, followed by Gran. We explain this by their free distribution, convenient and clear interface, as well as sufficient tools for solving school problems. Also, the use of Geogebra and Mathkit tools is often provided by educational programs for pre-service teachers of mathematics and computer science, in particular when studying teaching methods - this could be another reason for their popularity in teacher work. 
Note that a survey of a similar kind was conducted by us in 2014, so the results were expected (Semenikhina \& Drushlyak, 2015).

According to the results of the surveys, the most common in the educational and professional activities of mathematics and computer science teachers are the second type of software - programs Geogebra and Mathkit.

We will now discuss the results of task 3 . In accordance with the results of the analysis of computer tools for dynamic mathematics, a list was created (Table 3).

Table 3.

\section{Computer tools embedded in the DGS}

\begin{tabular}{|c|c|c|c|c|c|c|c|c|c|c|}
\hline Tool available from the panel or menu & טי & $\begin{array}{l}\bar{\tau} \\
\frac{\pi}{0} \\
\frac{\pi}{0}\end{array}$ & 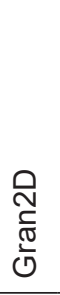 & $\begin{array}{l}\text { Oे } \\
\stackrel{\mathbb{\pi}}{\mathbb{\pi}} \\
\frac{0}{0}\end{array}$ & 咅 & 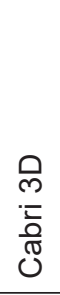 & $\begin{array}{l}\pi \\
0 \\
0 \\
0 \\
0 \\
0 \\
0 \\
0\end{array}$ & $\begin{array}{l}0 \\
10 \\
\pi \\
00 \\
0 \\
0 \\
0 \\
0 \\
0 \\
0\end{array}$ & 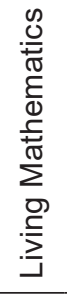 & 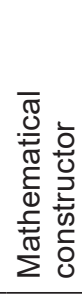 \\
\hline 1 & 2 & 3 & 4 & 5 & 6 & 7 & 8 & 9 & 10 & 11 \\
\hline 1. Calculator & + & + & + & + & - & - & + & + & + & + \\
\hline $\begin{array}{l}\text { 2. Construction of a point, line, ray, } \\
\text { segment, circle }\end{array}$ & + & - & + & - & + & + & + & + & + & + \\
\hline $\begin{array}{l}\text { 3. Construction of the middle of the } \\
\text { segment, bisector }\end{array}$ & + & - & + & - & + & + & + & + & + & + \\
\hline 4. Construction of an arc & + & - & + & - & + & + & + & + & + & + \\
\hline 5. Construction of a sector, segment & - & - & - & - & + & - & + & + & - & + \\
\hline $\begin{array}{l}\text { 6. Construction of a perpendicular or } \\
\text { parallel line }\end{array}$ & + & - & + & - & + & + & + & + & + & + \\
\hline $\begin{array}{l}\text { 7. Division of a segment or angle into } \\
\text { parts }\end{array}$ & - & - & - & - & + & - & - & - & - & + \\
\hline $\begin{array}{l}\text { 8. Determination of length, angle, } \\
\text { area }\end{array}$ & + & - & + & + & + & + & + & + & + & + \\
\hline 9. Construction of a polygon & + & - & \pm & - & + & + & + & + & + & + \\
\hline $\begin{array}{l}\text { 10. Construction of a tangent to a } \\
\text { curve }\end{array}$ & - & - & \pm & - & - & - & + & + & - & + \\
\hline $\begin{array}{l}\text { 11. Construction of a function graph } \\
\text { given explicitly and implicitly }\end{array}$ & - & + & - & + & - & \pm & । & 1 & \pm & + \\
\hline $\begin{array}{l}\text { 12. Construction of a function graph } \\
\text { given parametrically }\end{array}$ & - & + & - & - & - & - & 1 & 1 & \pm & + \\
\hline $\begin{array}{l}\text { 13. Construction of an interpolation } \\
\text { polynomial }\end{array}$ & - & + & + & - & - & - & + & + & - & + \\
\hline
\end{tabular}


Application of Computer Mathematical Tools in University Training of Computer Science...

1

14. Convert function graphs

15. Actions on sets

16. Construction of a polyhedral

17. Spatial objects management

18. Construction of a plane, a halfplane, a selection of a face of a polyhedron, construction of a cylinder, a cone, a sphere

19. Calculation of definite integrals, solving equations and inequalities of different types, their systems $\begin{array}{llllllllll}2 & 3 & 4 & 5 & 6 & 7 & 8 & 9 & 10 & 11\end{array}$

$-\quad-\quad-\quad-\quad-\quad-\quad-\quad+$

$-\quad-\quad-\quad-\quad-\quad-\quad-\quad+$

$-\quad-\quad+-+-\quad+-\frac{-}{-}$

$-\quad-\quad+\quad-\quad+\quad+\quad-\quad-$

$-\quad-\quad+\quad-\quad+\quad-\quad \pm \quad-\quad-$

20. Statistical processing of results

This list is sufficient to solve the typical problems of the school course of mathematics. We also analyzed the methodological tools provided by the developers of the second type of programs (Table 4 ).

Table 4.

Methodical methods provided in DGS

\begin{tabular}{|c|c|c|c|c|c|c|c|c|c|c|}
\hline Characteristic & ல & $\frac{-}{\frac{\pi}{0}}$ & 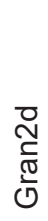 & 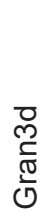 & $\frac{\bar{\nu}}{\sqrt{0}}$ & 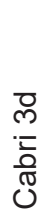 & 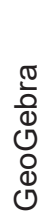 & $\begin{array}{l}0 \\
0 \\
0 \\
0 \\
0 \\
0 \\
0 \\
0 \\
0 \\
0\end{array}$ & 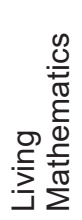 & 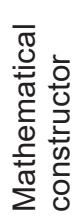 \\
\hline Step-by-step animation & * & - & * & - & * & * & * & * & * & * \\
\hline Creating of own tools & * & - & * & - & - & - & * & * & * & * \\
\hline $\begin{array}{l}\text { Setting marks on the } \\
\text { object }\end{array}$ & - & - & - & - & - & - & * & * & - & * \\
\hline Image restrictions & - & - & - & - & - & - & - & - & - & * \\
\hline Built-in demonstrations & - & - & - & - & - & - & - & - & - & * \\
\hline $\begin{array}{l}\text { Set the type and color } \\
\text { of objects }\end{array}$ & * & * & * & * & * & * & * & * & * & * \\
\hline Installing buttons & - & - & - & - & * & * & * & * & * & * \\
\hline Hiding objects & * & * & * & - & * & * & * & * & * & * \\
\hline Organization of control & - & - & - & - & - & - & - & - & - & * \\
\hline Dynamic trail & $*$ & - & * & - & * & * & * & * & * & * \\
\hline
\end{tabular}


As can be seen from Table 4, the MathKit program provides the greatest methodological support for teachers, as it allows enhancing the effect of learning by creating your tools, setting marks on the object, the ability to restrict images, use built-in demonstrations, set buttons, hide objects and organize automated control over mathematical solutions - these functions are not always avaliable in other programs.

To perform task 4 of our study, the results of an expert survey provided the following list of problems which mathematics and computer science teachers face or may face when using the second type of specialized software.

1. The use of DGS requires rethinking of forms and methods of training by a teacher. The traditional solution to the problem from the textbook with the help of software is not always advisable. As an example, problems for the transformation of expressions require an understanding of formulas, geometric problems for proof require additional initial training, a large number of tasks involves simply practicing a particular skill (counting, simplifying, calculating). At the same time, if the teacher plans to involve a computer, it is worth using tasks that provide some research without reference to specific data numbers.

Thus, the study of the sine theorem may not be conducted through direct proof of this theorem, but rather through the empirical study of the sides and angles of a triangle: "In a triangle opposite a smaller angle lies always a smaller side, etc." Pupils should record the results of twenty studies in a table (Table 5) for each type of triangle (equilateral, isosceles, versatile obtuse, versatile acute) and draw the appropriate conclusions. Empirical results must then be proved mathematically, but as practice shows, empirically obtained results are better mastered.

Table 5

Table of research result

\begin{tabular}{|c|c|c|c|c|c|c|c|c|}
\hline $\begin{array}{c}\text { Triangle } \\
\text { parameter }\end{array}$ & Side a & Angle A & Side b & Angle B & Side c & Angle C & $\begin{array}{c}\text { Smallest } \\
\text { angle } \\
\text { (letter) }\end{array}$ & $\begin{array}{c}\text { Smallest } \\
\text { side } \\
\text { (letter) }\end{array}$ \\
\hline \multicolumn{9}{|l|}{$\begin{array}{l}\text { Experiment } \\
\text { №1 }\end{array}$} \\
\hline \multicolumn{9}{|l|}{$\begin{array}{l}\text { Experiment } \\
\text { № } 2\end{array}$} \\
\hline \multicolumn{9}{|l|}{$\begin{array}{l}\text { Experiment } \\
\text { № } 3\end{array}$} \\
\hline \multicolumn{9}{|l|}{$\cdots$} \\
\hline $\begin{array}{l}\text { Experiment } \\
\text { № } 20\end{array}$ & & & & & & & & \\
\hline
\end{tabular}

IJREL.2020.6.2.06 p. 10/23 
Application of Computer Mathematical Tools in University Training of Computer Science...

2. The DGS use requires the search for non-standard and creative tasks. This is because modern pedagogical theory and practice promote the development of the creative abilities of pupils, including the use of ICT. It is known that one of the components of creative thinking is intuition. It is the content of mathematical problems that determines its development. Scientists claim that solving problems best promotes the development of observation, the ability to apply visual thinking, and other faculties.

We have also noted that the realization of interdisciplinary connections contributes not only to the formation of skills to model objects of different nature but also to the better assimilation of the subject and increased knowledge of the subject. In particular, it is proposed to visualize molecules and atoms of substances, whose structure is subject to symmetry laws or to model the water movement in a garden hose under the influence of gravity.

3. The problem of environment-rational choice. Our observations have shown situations when the problem is solved using a computer tool which is not optimal. However, this problem is easy to solve when you already have experience with such tools and identify opportunities for their use in maths lessons. Thus, it is not always appropriate to involve the program Gran3d to solve stereometry problems, because its limited tools (creation of basic stereometric objects, parallel transfer, and rotation) does not allow for operatation with equations of objects and their transformations (the program Cabri $3 D$ does not provide for the assignment of objects by their equations either). Instead, GeoGebra 5.0 will successfully assist in solving problems set analytically.

4. To check the results of solving the problem using a computer program. It is important to understand the pupil's approach to creating a solution. Thus, the problem of constructing a square can be solved in several ways, not all of which will be correct (for example, the construction of lines which are visually perpendicular to each other, but do not retain this property with a dynamic change of design).

5. Standard errors when using computer tools. Such errors include incorrect command syntax, incorrect use of the tool, lack of understanding of the result of the tool's impact on the object, inability to explain the obtained solutions following the use of the tool, and so on.

Typical errors are not limited to those given above. Focusing on them adds confidence that pre-service teachers will be able to avoid the same mistakes. Therefore, it is extremely important to have a clear presentation of the training material, a well-chosen system of exercises, recommendations which prevent the implementation of incorrect actions.

So, the list of problems which mathematics and computer science teachers face or may face when using specialized software of the second type, includes the following: the need to rethink the established forms and methods of teaching by 
the teacher, the problem of a constant search for non-standard and creative tasks, the problem of software rational choice; the problem of checking the obtained computer's result, the problem of common errors in the use of computer tools. The assessment of the experts' consistency opinions was based on the Kendall concordance coefficient and amounted to 0.75 (Table 6).

Table 6

Distribution of expert's opinions

\begin{tabular}{ccccccc}
\hline & Expert 1 & Expert 2 & Expert 3 & Expert 4 & Expert 5 & Expert 6 \\
\hline Problem 1 & 1 & 1 & 1 & 1 & 1 & 2 \\
Problem 2 & 2 & 3 & 2 & 2 & 2 & 1 \\
Problem 3 & 4 & 5 & 4 & 4 & 4 & 4 \\
Problem 4 & 3 & 2 & 3 & 3 & 3 & 3 \\
Problem 5 & 5 & 4 & 5 & 5 & 5 & 5 \\
\hline
\end{tabular}

Since the value of the coefficient is more than 0.5 , there is reason to speak about the consistency of experts' opinions on several problems faced by teachers in order to rationally and prudently approach the involvement of specialized software in professional activities. Testing the hypothesis on the significance of the concordance coefficient according to Pearson's criterion $\left(\mathrm{H}_{0}\right.$ : the value of the concordance coefficient is random; $\mathrm{H}_{1}$ : the value of the concordance coefficient is significant) also confirms these conclusions (the value $\chi^{2}$ empirical is 11.714 , which is more than $\chi^{2}$ critical 11.07 for the significance level of 0.05 and $6-1=5$ degrees of freedom). These problems can be eliminated provided that mathematics and computer science teachers are prepared for the creative choice of forms and methods of teaching, the ability to find non-standard or creative mathematical problems, the ability to make an informed choice of specialized software, a vision of possible ways to check the computer result obtained by the pupil and typical errors in the use of computer tools.

It should also be noted that conducted expert analysis was taken into account to improve the educational programs for the training of mathematics and computer science pre-service teachers. In particular, we have expanded the content of the course "Teaching Methods" with a separate module "Teacher's problems when using specialized software." In addition, we have developed and proposed a elective special course "The use of computers in teaching mathematics." One of the tasks in the formation of mathematics and computer science pre-service teachers is the ability to rationally choose dynamic geometry software to solve certain classes of mathematical problems and the development of creative skills in reformulating textbook problems. 
Application of Computer Mathematical Tools in University Training of Computer Science...

To perform task 5 to clarify the list of skills required for mathematics and computer science teachers to use specialized mathematical software in professional activities, an extended analysis of the mathematics school course topics in a primary school was conducted to support them with computer-aided mathematical tools, identified during the analysis of the relevant environments. Such an analysis, along with the study of mathematical education standards, revealed that the requirements for the training of specialists are formulated too "broadly." In particular, the level of standard for pre-service mathematics teachers in the use of special computer programs is defined only as an ability to select and use ready-made software (mathematical application packages) for symbolic, graphical, numerical analysis of mathematical models of real objects. There is no clarification of the computer tools list or their types, methods of their study, or methods of use at the task level of quantitative content or competence.

This led to further research in the direction of clarifying the computer tools list which should be in the arsenal of modern mathematics teachers from the standpoint of state requirements for teacher training.

Clarification of the computer mathematical tools list necessary for a modern mathematics teacher was implemented by us in the typical tasks of the school mathematics course, existing mathematical software, requirements for primary school graduates and educational standards of higher education (Mathematics. State standard of basic and complete secondary education. Educational branch "Mathematics," 2004).

Therefore, the generalization of our previous research, as well as the analysis of educational standards for higher education and secondary schools, curricula for computer science and mathematics teachers allowed to specify and harmonize the requirements of the pedagogical education standard, the need for school mathematics and a list of teacher skills in using specialized software (Table 7).

The described analysis and refinement of standards allow to single out those educational tasks whose solution will ensure the formation of computer science and mathematics pre-service teachers the ability to use computer mathematical tools in professional activities:

- formation of competence for solving standard problems of the school algebra and geometry course with the use of computer mathematical tools;

- formation of integral computer mathematical tools as one of the teaching aids;

- formation of skills taking into account the chosen method of training to choose the expedient computer mathematical tool;

- formation of skills to choose the best of the available computer mathematical tools for the implementation of various tasks. 


\section{Table 7}

Skills of math and computer science teachers

\begin{tabular}{|c|c|}
\hline Standard requirement & $\begin{array}{l}\text { Clarification of the requirement in the } \\
\text { context of the study }\end{array}$ \\
\hline $\begin{array}{c}\text { Be able to select and use ready-made } \\
\text { software tools (mathematical application } \\
\text { packages) for symbol-formula, graphic, } \\
\text { numerical analysis of mathematical mod- } \\
\text { els of real objects }\end{array}$ & $\begin{array}{l}\text { Be able to use specialized software of the } \\
\text { second type (DGS). Be able to choose the } \\
\text { best of the available mathematical com- } \\
\text { puter tools to visualize the condition, step- } \\
\text { by-step demonstration of the solution, } \\
\text { accelerate the result, check the answer }\end{array}$ \\
\hline $\begin{array}{c}\text { Possess the use of computer, numeri- } \\
\text { cal and graphic information processing } \\
\text { systems, subject-oriented application } \\
\text { systems }\end{array}$ & Possess the tools of programs of DGS \\
\hline $\begin{array}{l}\text { Be able to compose programs for solving } \\
\text { typical educational problems }\end{array}$ & $\begin{array}{c}\text { Be able to solve typical problems of } \\
\text { school mathematics course topics with the } \\
\text { use of computer tools }\end{array}$ \\
\hline $\begin{array}{l}\text { Be able to choose tools and methods of } \\
\text { teaching using computer technology }\end{array}$ & $\begin{array}{l}\text { Be able to choose the appropriate com- } \\
\text { puter tool, taking into account the chosen } \\
\text { method of teaching }\end{array}$ \\
\hline $\begin{array}{l}\text { Be able to use computer-oriented systems } \\
\text { of teaching disciplines in their specialty }\end{array}$ & $\begin{array}{c}\text { Be able to use a computer tool and teach } \\
\text { students to use it independently } \\
\text { Be able to creatively choose the forms } \\
\text { and methods of teaching for the use of } \\
\text { specialized software } \\
\text { Ability to find non-standard or creative } \\
\text { mathematical problems } \\
\text { Ability to make an informed choice of } \\
\text { specialized software } \\
\text { Be able to see possible ways to check } \\
\text { computer result obtained by the pupil } \\
\text { Ability to correct common mistakes when } \\
\text { pupils use computer tools }\end{array}$ \\
\hline
\end{tabular}

\section{Discussion}

In the previous works of the authors of this study, V. Proshkin and O. Semenikhina, it was established that in the system of Ukrainian mathematical education there is terminology which characterizes its informatization. Among them is mathematical software, by which are meant tools whose functionality is focused on solving certain classes of mathematical problems, and pedagogical software, which 
Application of Computer Mathematical Tools in University Training of Computer Science...

means a kind of electronic educational resources that requires the involvement of certain types of computer technology (computer, smartphone, tablet, etc.), is used for a specific pedagogical purpose and serves to support the educational process (Astafieva, Bodnenko \& Proshkin, 2019; Semenikhina, Drushlyak, Shishenko \& Zigunov, 2018). One of the important characteristics of pedagogical software is interactivity, which is the direct response of the system to user actions. Given this, some mathematical software which allows you to organize an interactive research process or interactive visualization of analytical or geometric properties of a particular mathematical object or structure can be considered pedagogical and should be used in mathematical training.

A review of the scientific methodological literature in the field of teaching mathematics shows that two classes of mathematical software are studied in general, although at the same time software developers offer a wide range of narrowly oriented programs (graph plotters, mathematical statistics systems, etc.). The first class includes computer algebra system (Maple, MatLab, Maxima, etc.). These systems are especially effective in solving a variety of applied problems, especially problems of mathematical modeling in science and technology. The second class includes programs of dynamic geometry software (DGS), which provide not only the ability to draw accurate figures, build various graphs, find the roots of equations, inequalities, and their systems, etc., which is difficult without the environment, but also the possibility of dynamic changes of mathematical construction, the study of its numerical characteristics or their relations in the dynamics: GeoGebra, Mathkit or Mathematical Constructor, DG, Gran, Cabri, Living Mathematics, etc. (Althoen, 2009; Hohenwarter, 2008).

The interfaces of the mentioned programs and their principles are very similar: through the use of the mouse and the toolbar mathematical objects such as functions and graphs can be represented, calculations can be done, certain geometric objects (points, lines, segments, circles, as well as their constructions) can be created, dynamic changes can be made, certain properties fixed to calculate values of lengths, angles, areas, etc. It should be noted that the analysis of the existing scientific and methodological bank revealed some terminological limitations regarding the designation of software actions (the available terms being "service," "tool," "team," "means"). There is no correlation between these concepts in the works of scientists, so in the context of our study, we define the essence of a computer mathematical tool: we consider a computer tool as a certain virtual algorithm (a mechanism), which can be separate or in the environment of a computer program. It can be used to affect the object to obtain the desired result.

Mathematical tools are tools used to analyze various objects (phenomena), investigating their numerical or geometric characteristics. They are usually used in the process of calculating, measuring, or constructing various geometric shapes.

IJREL.2020.6.2.06 p. 15/23 
The given definitions allow us to specify the term "computer mathematical tool" as a virtual algorithm (a mechanism) of a computer program (the program itself), used to develop and study mathematical objects (their components) through different numerical and geometric characteristics of existing objects.

Taking into account the above given definition, we have analyzed several computer algebra systems to identify their computer mathematical tools. We strongly believe that these programs are computer mathematical tools and also perform the functions of a specific environment, where there is a subset of different computer tools.

Our research additionally raised the question of the minimum number of computer mathematical tools sufficient for the professional activity of computer science and mathematics teacher. The experts suggested to proceed from the analysis of typical problems in a school mathematics course, whose solution requires a certain list of computer mathematical tools, analysis of available tools in DGS, teachers' experience in using DGS in mathematics teaching, and, taking into account the results of students' achievements, re-service computer science and mathematics teachers. The results of this analysis showed the need to master various tools. Note that many of them are embedded in the DGS Living Mathematics, which is not very popular with both students and teachers because of the ascetic interface, from which we conclude that there is an excess stock of computer mathematical tools in all other DGS.

It is worth noting that the developers of information products are modernizing them in the context of expanding opportunities to solve various problems, as well as providing procedures to simplify the implementation of the educational process. Such modifications include a step-by-step demonstration and the ability not to show individual objects and texts. A modern version of several programs, Mathematical Constructor for example, also provides test control of knowledge.

Let us list and outline the methodical features of the application of computer mathematical tools. They include:

- the ability to change the pattern in the dynamics, observation of the trajectories of points. This allows for a better organization and implementation of research activities of the educational process (pupils have some tools for mathematical discovery, the teacher has a pedagogical way which contributes to a high-quality understanding of the mathematical idea);

- the ability to expand the set of tools for constructing the middle of a segment, parallel to a line or perpendicular, the installation of tools which have already been used. As practice shows, this simplifies the construction process;

- the computer helps the computer science and mathematics teacher to verify the correctness of difficult constructions. It is interesting that in some computer 
Application of Computer Mathematical Tools in University Training of Computer Science...

systems, for example, at Mathematical Constructor, the check is performed automatically.

We see the solution to erroneous problem solving with the use of DGS in the introduction of such learning technology, which would allow to verify the result, in particular when using multiple DGS, parallel involvement of analytical methods, as well as when using tasks with insufficient, redundant data, contradictions, as well as creative and exploratory tasks.

Therefore, the appropriate preparation of teachers for the effective use of computer mathematical tools is especially important. It is important to define each task and tools for solving, but also to arrange the selected tasks in such a sequence that they are initially simple and feasible for most pupils and their complexity gradually increases. The practice has shown that if a pupil feels that the task is too complex, he moves on to solving simpler problems, including those in another virtual environment.

We implemented the clarification of the computer mathematical tools list required for computer science and mathematics teachers in the typical tasks from school mathematics course, the current mathematical software tools, the requirements for primary school graduates, and the educational standards of higher education. We also identified a list of topics for the appropriate use of computer mathematical tools, indicated the programs where these tools are provided, indicated the availability of computer tools for individual programs in studying school mathematics courses (also gave the conditions of typical problems).

An interesting result of our study was an experiment related to the study of the impact of DGS on the level of pupil's achievement. It was conducted by pre-service computer science and mathematics teachers after mastering a special course related to the study of computer mathematical tools.

During the 2018-2019 academic year, fourth-year students majoring in mathematics at Makarenko Sumy State Pedagogical University proposed as a diploma project to lead a student academic society whose main purpose was to solve mathematical problems in DGS environments. Students developed the program of the circle, selected problems of different complexity levels and according to their preferences one could choose the DGS. It was necessary to investigate whether the use of computer mathematical tools affected the level of pupil achievement.

This level was checked by the tasks of the SFE at the beginning of the circle's activity and once it ceased.

Pupils of 9th grade of schools in the Sumy region took part in the experiment. The total number was 72 people.

The pupils were asked to answer the test questions at the beginning and at the end of group meeting, the list of tasks and answers was positively assesed by 
experts in the mathematic field. The test was positioned as one which checks the level of 9th-grade pupils' mathematical training.

The maximum number of test scores was 25 .

The general level of academic achievement and its dynamics was monitored by students. Since the scale of names had two positions correct/incorrect, the results of each sample members were dependent, but as the results between the sample members were mutually independent we used the criterion of signs to process the overall results.

The null hypothesis is that the work of the circle does not affect the quality of pupils' mathematical training. Alternative - the quality of mathematical training will change.

At the significance level, 0,05 is the critical value of statistic Gcrit $=28$.

Table 8 shows the test results.

\section{Table 8}

\section{Pupils' test results}

\begin{tabular}{cccccccccccc}
\hline $\begin{array}{c}\text { № } \\
\text { resp. }\end{array}$ & $\begin{array}{c}\text { Type of } \\
\text { change }\end{array}$ & $\begin{array}{c}\text { №sp. } \\
\text { resp. }\end{array}$ & $\begin{array}{c}\text { Type of } \\
\text { change }\end{array}$ & $\begin{array}{c}\text { № } \\
\text { resp. }\end{array}$ & $\begin{array}{c}\text { Type of } \\
\text { change }\end{array}$ & $\begin{array}{c}\text { № } \\
\text { resp. }\end{array}$ & $\begin{array}{c}\text { Type of } \\
\text { change }\end{array}$ & $\begin{array}{c}\text { № } \\
\text { resp. }\end{array}$ & $\begin{array}{c}\text { Type of } \\
\text { change }\end{array}$ & $\begin{array}{c}\text { № } \\
\text { resp. }\end{array}$ & $\begin{array}{c}\text { Type of } \\
\text { change }\end{array}$ \\
\hline 1 & 0 & 13 & 5 & 25 & -2 & 37 & -1 & 49 & 0 & 61 & 0 \\
2 & 2 & 14 & 3 & 26 & -2 & 38 & -2 & 50 & 4 & 62 & 0 \\
3 & 4 & 15 & 2 & 27 & -1 & 39 & -4 & 51 & 2 & 63 & 2 \\
4 & -1 & 16 & 6 & 28 & 6 & 40 & -2 & 52 & 3 & 64 & -2 \\
5 & -3 & 17 & -4 & 29 & 2 & 41 & 3 & 53 & 1 & 65 & -1 \\
6 & 0 & 18 & -1 & 30 & 5 & 42 & 3 & 54 & 1 & 66 & -3 \\
7 & -2 & 19 & 0 & 31 & 6 & 43 & 0 & 55 & 1 & 67 & -1 \\
8 & 0 & 20 & -2 & 32 & 3 & 44 & 2 & 56 & -1 & 68 & 2 \\
9 & -1 & 21 & -1 & 33 & -2 & 45 & 0 & 57 & -2 & 69 & 2 \\
10 & 2 & 22 & 6 & 34 & -3 & 46 & 3 & 58 & 2 & 70 & -1 \\
11 & 3 & 23 & 2 & 35 & -1 & 47 & 3 & 59 & 2 & 71 & -1 \\
12 & 2 & 24 & 3 & 36 & -1 & 48 & 0 & 60 & 2 & 72 & 2 \\
\hline
\end{tabular}

According to the rules of decision-making, we have that Gemp. $=27$. Since the empirical value is less than critical, an alternative hypothesis is accepted about the impact of the group work on the quality of pupils' mathematical training, and this impact is positive because the number of positive shifts (35 respondents increased) exceeds the number of negatives ( 27 respondents showed a decrease in overall score test).

In other words, there is a reason to speak about the positive impact of DGS use and relevant mathematical tools on the level of schoolchildren's mathematical 
Application of Computer Mathematical Tools in University Training of Computer Science...

training, and therefore there is a reason to talk about the importance of training pre-service computer science and mathematics teachers to involve such tools in their professional activities.

\section{Conclusions}

A survey of university lecturers and school teachers in Ukraine established that the most common specialized software for teaching mathematics are Maple, Maxima, Mathlab (CAS) and Geogebra, and Mathkit (DGS). The factors influencing the popularity of using these programs in teaching mathematics were highlighted. This made it possible to analyze the available computer tools and compile a list of computer tools which are most in-demand in the work of mathematics and computer science teachers. Methodological receptions that were provided by developers of DGS programs were analyzed.

As a result of an expert survey of teachers-methodologists, the most pressing problems faced by mathematics and computer science teachers when using DGS were identified. The assessment of the experts' opinions consistency is based on the Kendall concordance coefficient. This allowed us to identify the requirements for the training of mathematics and computer science teachers to use specialized software for mathematics in professional activities. These include the ability to creatively choose the forms and methods of specialized software, the ability to find non-standard or creative mathematical problems, the ability to make an informed choice of specialized software, a vision of possible ways to check the computer result obtained by the pupil, skills to eliminate the common mistakes when pupils use computer tools.

To clarify the list of skills required for mathematics and computer science teachers to use in professional activities of specialized mathematical software and to support them with computer mathematical tools, the analysis of the school mathematics course topics of primary school has been carried out. The list of computer tools that should be in the arsenal of a modern mathematics and computer science teacher was specified.

As a result of an experiment related to the study of DGS influence on the level of pupils achievement, a positive effect of DGS use on the level of schoolchildren mathematical training has been established (using the G-criterion of signs). This determines the importance of preparing pre-service computer science and mathematics teachers to use DGS in professional activities. 
We see the prospect of further scientific research in the development of methods for using computer mathematical tools in a learning environment based on research. We also consider it appropriate to analyze the application of computer mathematical tools in university training of computer science and mathematics pre-service teachers in different countries.

\section{References}

Althoen, S. (2009). Investigating Bricard's proof of Morley's theorem with the Geometer's sketchpad. Mathematics Teacher, 9, 706-709.

Astafieva, M., Bodnenko, D., \& Proshkin, V. (2019). Cloud-oriented training technologies as a means of forming the XXI century skills of future mathematics teachers. CEUR Workshop Proceedings, 2387, 507-512.

Botana, F., Hohenwarter, M., Yanichich, P., Recio, T., \& Weitzhofer, S. (2015). Automated theorem proving in GeoGebra: Current achievements. Journal of Automated Reasoning, 55(1), 39-59.

Dziabenko, O., Morze, N., Vasylenko, S., Varchenko-Trotsenko, L., Vember, V., Boiko, M., Vorotnykova, I., \& Smyrnova-Trybulska, E. (2020). Innovative pedagogical methods in the digital age. Borys Grinchenko Kyiv University.

Dubrovskyi V. N. (2016). "1C: Mathematical constructor" and mathematical practicum in MSY. Informatics and Education, 7(276), 22-26.

Heba, A., Kapounová, J., \& Smyrnova-Trybulska, E. (2014). Theoretical conception and some practical results of the development of mathematical competences with the use of e-learning. International Journal of Continuing Engineering Education and Life-Long Learning, 24(3-4), 252-268.

Henseruk, H. (2019). Some advanced experience of the development of teachers' digital competence. International Journal of Research in E-Learning, 5(1), 61-79.

Hohenwarter, M., \& Preiner, J. (2007). Dynamic mathematics with GeoGebra. Journal of Online Mathematics and its Applications, 7, 1448.

Hohenwarter, M. (2008). Introducing dynamic mathematics software to secondary school teachers: The case of GeoGebra. Journal of Computers in Mathematics and Science Teaching, 28, $135-146$.

Mathematics. State standard of basic and complete secondary education. Educational branch "Mathematics" (2002). Retrieved from http://zakon.rada.gov.ua/rada/show/v0546290-02\#Text.

Morozova E. V., \& Miroshkina O. S. (2013). Training toolkit "Living Mathematics" as a virtual mathematical laboratory. Computer mathematics systems and their applications, 14, 236-240.

Saha, R. A., Ayub, A. F. M., \& Tarmizi, R. A. (2010). The effects of GeoGebra on mathematics achievement: Enlightening coordinate geometry learning. Procedia-Social and Behavioral Sciences, 8, 686-693.

Semenikhina, E., Drushlyak, M., Shishenko, I., \& Zigunov, V. (2018). Using a praxeology approach to the rational choice of specialized software in the preparation of the computer science teacher. TEM Journal, 7(1), 164-170.

IJREL.2020.6.2.06 p. 20/23 
Application of Computer Mathematical Tools in University Training of Computer Science...

Semenikhina, O., \& Drushlyak, M. (2015). On the results of a study of the willingness and the readiness to use dynamic mathematics software by future math teachers. CEUR Workshop Proceedings, 1356, 21-34.

Stols, G., \& Kriek, J. (2011). Why don't all maths teachers use dynamic geometry software in their classrooms? Australasian Journal of Educational Technology, 27(1), 137-151.

Zengin, Y., Furkan, H., \& Kutluca, T. (2012). The effect of dynamic mathematics software GeoGebra on student achievement in the teaching of trigonometry. Procedia - Social and Behavioral Sciences, 31, 183-187.

Olena Semenikhina, Volodymyr Proshkin, Olha Naboka

\section{Zastosowanie komputerowych instrumentów matematycznych w przygotowaniu przyszlych nauczycieli informatyki i matematyki na uniwersytetach}

\section{Streszczenie}

W artykule uzasadniono wymagania stawiane kształceniu nauczycieli matematyki i informatyki w kontekście wykorzystania specjalistycznego oprogramowania na kierunku matematycznym w działalności zawodowej. Wśród nich: umiejętność twórczego doboru form i metod nauczania obsługi specjalistycznego oprogramowania; umiejętność znajdowania niestandardowych lub kreatywnych problemów matematycznych; umiejętność dokonania wyważonego wyboru specjalistycznego oprogramowania; możliwość zobaczenia możliwych sposobów sprawdzenia wyniku uzyskanego przez ucznia; umiejętność eliminowania typowych błędów przy korzystaniu z narzędzi komputerowych itp. Doprecyzowano specjalistyczne oprogramowanie kierunku matematycznego, które jest obecnie wykorzystywane w kształceniu matematycznym nauczycieli matematyki i informatyki na Ukrainie. Przedstawiono specjalistyczne oprogramowanie kierunku matematycznego, które jest dziś używane do nauczania matematyki w ukraińskich szkołach. Dokonuje się analizy narzędzi komputerowych wykorzystywanych przez nauczyciela we wspólnym oprogramowaniu kierunku matematycznego. Zwrócono uwagę na najpilniejsze problemy, z którymi borykają się nauczyciele matematyki w swojej działalności zawodowej. W wyniku eksperymentu z uczniami klas 9 wykazano pozytywne uwarunkowanie stosowania dynamicznych układów geometrycznych i odpowiednich narzędzi matematycznych na poziom przygotowania matematycznego uczniów, co jest podstawą do rozmowy o znaczeniu przygotowania przyszłych nauczyciel informatyki i matematyki do wykorzystania takich narzędzi we własnej działalności zawodowej. Przedstawiono perspektywy dalszych badań naukowych w kontekście opracowania metodologii wykorzystania komputerowych narzędzi matematycznych w uczeniu się opartym na badaniach.

S łow a kluc zow e: komputerowe narzędzia matematyczne; dynamiczne oprogramowanie geometryczne; systemy algebry komputerowej; przyszły nauczyciel informatyki; przyszły nauczyciel matematyki; Edukacja na Uniwersytecie 
Елена Семенихина, Владимир Прошкин, Ольга Набока

\title{
Применение компьютерных математических инструментов в университетской подготовке будущих учителей информатики и математики
}

\author{
А н но т а ци я
}

В статье обоснованы требования к подготовке учителей математики и информатики в контексте использования специализированного программного обеспечения математического направления в профессиональной деятельности. Среди них: умение творчески выбирать формы и методы обучения использования специализированного программного обеспечения; умение находить нестандартные или творческие математические задачи; умение осуществить взвешенный выбор специализированного программного обеспечения; умение видеть возможные пути проверки полученного учеником результата; умение устранять типовые ошибки при применении учеником компьютерных инструментов и т.д. Уточнено специализовананое программное обеспечение математического направления, которое сегодня используется в математической подготовке учителей математики и информатики в Украине. Представлено специализированное программное обеспечение математического направления, которое сегодня используется для обучения математики в школах Украины. Осуществлен анализ компьютерных инструментов, используемых учителем в распространенного программного обеспечения математического направления. Выделены наиболее актуальные проблемы, с которыми сталкиваются учителя математики в профессиональной деятельности. В результате эксперимента с учениками 9-х классов доказано положительное влияние использования динамических геометрических систем и соответствующего математического инструментария на уровень математической подготовки школьников, ято является основанием говорить о важности подготовки будущего учителя информатики и математики к использованию такого инструментария в собственной профессиональной деятельности. Представлены перспективы дальнейших научных поисков в контексте разработки методики использования компьютерных математических инструментов в условиях обучения, основанного на исследованиях.

К л ю ч е в ы е с л о в а: компьютерные математические инструментарии; динамическое геометрическое програмное обеспечение; системы компьютерной алгебры; будущий учитель информатики; будущий учитель математики; университетское образование

IJREL.2020.6.2.06 p. 22/23 
Application of Computer Mathematical Tools in University Training of Computer Science...

Olena Semenikhina, Volodymyr Proshkin, Olha Naboka

\title{
Aplicación de instrumentos matemáticos informáticos en la formación universitaria de futuros profesores de informática y matemáticas
}

\begin{abstract}
A notación
El artículo fundamenta los requisitos para la formación de profesores de matemáticas e informática en el contexto del uso de software especializado en la dirección matemática en actividades profesionales. Entre ellos: la capacidad de elegir creativamente las formas y métodos de enseñar el uso de software especializado; la capacidad de encontrar problemas matemáticos creativos o no estándar; la capacidad de realizar una elección equilibrada de software especializado; la capacidad de ver posibles formas de comprobar el resultado obtenido por el alumno; la capacidad de eliminar errores típicos cuando un estudiante usa herramientas informáticas, etc. Se ha aclarado el software especializado de la dirección matemática, que se utiliza actualmente en la formación matemática de profesores de matemáticas e informática en Ucrania. Se presenta el software especializado de la dirección matemática, que se utiliza hoy para enseñar matemáticas en las escuelas ucranianas. Se realiza el análisis de las herramientas informáticas utilizadas por el docente en el software común de la dirección matemática. Se destacan los problemas más urgentes que enfrentan los docentes de matemáticas en sus actividades profesionales. Como resultado del experimento con estudiantes de 9 grado, se comprobó la influencia positiva del uso de sistemas geométricos dinámicos y las herramientas matemáticas correspondientes en el nivel de formación matemática de los escolares, que es la base para hablar sobre la importancia de preparar un futuro. profesor de informática y matemáticas para utilizar dichas herramientas en sus propias actividades profesionales. Se presentan las perspectivas de futuras investigaciones científicas en el contexto del desarrollo de una metodología para el uso de herramientas matemáticas informáticas en el aprendizaje basado en la investigación.

Palabras clave: herramientas matemáticas informáticas; software de geometría dinámica; sistemas informáticos de álgebra; futuro profesor de informática; futuro profesor de matemáticas; educación universitaria
\end{abstract}

IJREL.2020.6.2.06 p. 23/23 
